\title{
ANCIENT REPERFORMANCES OF SOPHOCLES
}

The sheer length of Sophocles' career is humbling. Born some time in the 490s, he began to produce plays perhaps as early as the 470 s; certainly no later than 468 , when he won his first victory. ${ }^{1} \mathrm{He}$ died in 405 , leaving at least one work, his Oedipus at Colonus, to be performed posthumously; the production of Philoctetes in 409 is a further sign that he went on writing and putting on plays well into his eighties, perhaps even his nineties. Rather more than a hundred plays attributed to him survived to be catalogued at Alexandria in the third century; the most likely figure for the number of his plays known to Hellenistic scholars is $123 .^{2} \mathrm{He}$ almost certainly wrote more: it would be remarkable if not a single play from his evidently enormous output was lost between Athens and Alexandria. ${ }^{3}$ Even the 123 plays alone are equivalent to 30 or 31 separate entries in the Dionysia at Athens (where playwrights put on four plays at a time, three tragedies followed by a satyr-play), or slightly less than one entry every two years. It is likely that Sophocles put on plays at other festivals too, however, such as the Lenaea, where only two tragedies (and no satyrplay) were required of each competitor; ${ }^{4}$ so our evidence does not allow us to say for certain that he competed in the Dionysia biennially. What we can be sure of, besides the raw number of his plays, is his popularity. According to an inscription dating to $c$. $300 \mathrm{BC}$ he won eighteen first prizes at the Dionysia alone. ${ }^{5}$ Diodorus Siculus credits

I am grateful to Professor David Kovacs for helpful comments.

${ }^{1}$ See Finglass 2011, 1-2.

${ }^{2}$ Thus Sommerstein 2012, 192.

${ }^{3}$ For the transmission of Sophocles' plays see Finglass 2012.

${ }^{4}$ For the evidence see Sommerstein 2012, 193.

${ }^{5} \operatorname{Tr} G F$ I DID A 3a.15 = Millis and Olson 2012, 144. 
him with eighteen victories across his career, Carystius with twenty, the Suda with twenty-four; the Suda adds, perhaps on the authority of Carystius, that he was never placed last. ${ }^{6}$ Throughout his life Sophocles evidently retained the ability to delight audiences with newly-written dramas.

Sophocles' extraordinary, and extraordinarily successful, productivity might suggest at first sight that he was not much concerned with the reperformance of his works. His life seems to exemplify the principle enunciated by Telemachus in the Odyssey, that it is always the newest song that falls most welcome on a listener's ears. $^{7}$ A man who spent decades composing and producing new works with such regularity, we might think, would hardly have been able to put on his plays a second and third time, with all the demands of time, energy, and resources that this would bring. The time that Sophocles could have devoted to supervising reperformances would have been further reduced by his involvement, throughout his career, in the civic affairs of democratic Athens. ${ }^{8}$ We might ask what interest the audiences of tragedy would have taken in Sophoclean reperformances. Sophocles' career overlapped with Aeschylus' at its beginning, with Euripides' in its middle and end; so for decades spectators had the opportunity to see new plays virtually every year by the acknowledged masters of this genre, not to speak of other poets now lost whose work achieved celebrity in their day. With so many excellent new plays on offer, why should fifth-century spectators have taken an interest in old ones? And if they did,

\footnotetext{
${ }^{6}$ Diod. 13.103 .4 (test. $85 \operatorname{Tr} G F$ ), Carystius fr. 18 FHG (test. 1.33-4 TrGF), Suda o 815 (test. 2.10 $\operatorname{Tr} G F)$.

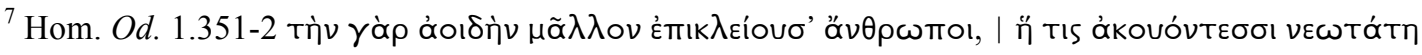

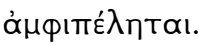

${ }^{8}$ For references and discussion see Scodel 2012, Tyrrell 2012.
} 
when and where did they get the opportunity to see them, given that the most prestigious competitions were open only to fresh work?

Against all this, however, and continuing for the moment to argue from first principles, we must set the fact that Sophocles' works survived. Texts did not last long in the ancient world if people were not interested in their contents. Sophocles no doubt kept copies of his own work, ${ }^{9}$ and admirers of his work could have done so too, if they had the money to acquire copies and the leisure to read them. But in a predominantly oral culture such as that of fifth-century Athens it is hard to imagine that so much text was preserved for so long merely as the preserve of readers. ${ }^{10}$ There would have been a strong impulse to perform these words, in whatever context. ${ }^{11}$ As for the point that Sophocles' incessant composition of popular works would have inhibited the reperformance of older works, this cuts both ways. True, many spectators were no doubt content to see each new Sophoclean tetralogy once, as it was produced; but thanks to Sophocles' popularity, for many people that will not have been enough. Just as fans of epic did not tire of hearing the most famous poems repeated, so too Sophoclean enthusiasts will have wanted to see individual plays more than once. In a later period Plato describes people addicted to tragedy chasing after performances, in whatever location; ${ }^{12}$ it would be foolish to deny that similar

\footnotetext{
${ }^{9}$ For the use of family archives to preserve texts in the classical period see Revermann 2006a, 84.

${ }^{10}$ Thus Easterling 2006, 4: 'we should be assuming that there was a close interconnection between the popularity of certain plays in the repertoire and the demand for written copies'.

${ }^{11}$ Cf. Csapo 2010, 97, on a poet from the previous generation: 'the survival of so many of Aeschylus' plays and fragments must be due to a strong reperformance tradition: we have no other significant remnants of drama from the first half of the fifth century'.

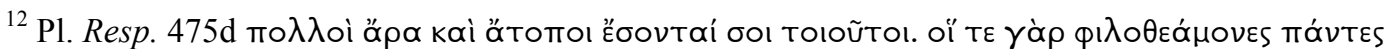

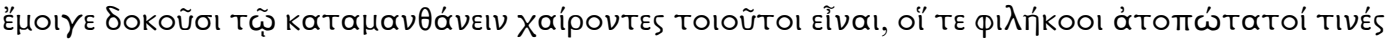


enthuasiasm could have existed before Plato's time, and if it did, there would have been pressure to create the infrastructure to present such entertainments. In addition, the length of Sophocles' career will have meant that only a tiny fraction of the audience of, say, Philoctetes (409) will have been present at the first performance of Triptolemus (468). Some, at least, would have wanted to appreciate the master's earlier works, which they had not had the chance to see when they were first produced.

It is time to turn from speculation to specifics; and while hard data for this topic is scarce, detailed analysis of what we have may be suggestive. From a chance remark in Herodotus we may conclude that tragic reperformance was already a part of Athenian culture when Sophocles was still a boy. In 492 Phrynichus' production of his tragedy The Capture of Miletus met with such a hostile response from the Athenians that they fined him a thousand drachmas and ordered that no-one should ever put the play on again. ${ }^{13}$ Such a ban would make no sense unless the reperformance of a tragedy was more than a remote possibility. ${ }^{14}$ The targeting of the prohibition is also significant: the Athenians prevent anybody, not just Phrynichus, from putting the play on a second time. This implies that somebody other than the

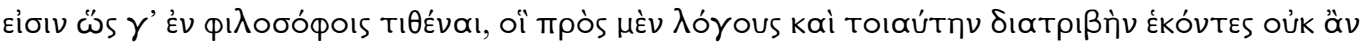

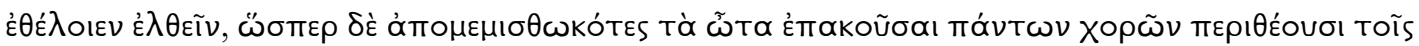

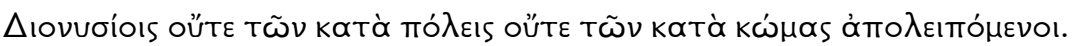

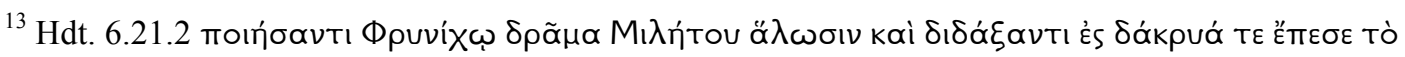

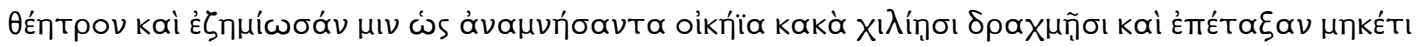

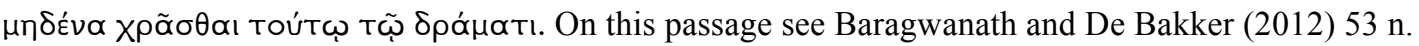
218.

14 Thus Taplin 1999, 37. 
author might instigate a reperformance. ${ }^{15}$ It might also be relevant that this prohibition was directed against a play which, on its first performance, was evidently a flop. Perhaps the prohibition was an excessive and unnecessary reaction against a work that no-one was ever going to reperform; equally, however, the Athenians who voted for the ban may have anticipated the possibility that, over time, opinions could change, and so someone might indeed attempt to stage a revival.

Behind Herodotus' brief remark, then, may lie a sophisticated culture of reperformance as early as the 490s; even initially unpopular plays could see more than one production, at the hands of different producers. These reperformances must have taken place outside the main festival of the Dionysia, which at that time admitted only new plays. The Athenian assembly must have had in mind reperformance in the Attic demes at the Rural Dionysia. ${ }^{16}$ Inscriptional evidence from the deme Ikarion attests a local theatrical festival from at least $c .450,{ }^{17}$ and this is unlikely to have been an isolated phenomenon. So when Revermann writes that in Attica there was probably 'a vibrant reperformance culture by the last quarter of the fifth century at the very latest', ${ }^{18}$ and Wilson that 'at least by the late fifth century, a number of wealthier

\footnotetext{
${ }^{15}$ So rightly Marshall 2012, 65-6 n. 24.

${ }^{16}$ For this festival see Jones 2004, 124-58; Csapo 2004a, 57-66; 2010, 89-95; Wilson 2010, 40-1 ('of the eighteen deme Dionysia for which we now have some solid evidence, at least fifteen included theatrical events'); Nervegna 2013, 21-3. It was generally held in the larger demes (Jones pp. 139-42), probably with 'a large local center with a theater catering to neighboring smaller demes, with occasional visits from the town' (ibid. 142).

${ }^{17}$ See $I G \mathrm{I}^{3}$ 253-4 with Wilson 2000, 79-80 and 2008, 90-1 with n. 11.

${ }^{18}$ Revermann 2006a, 68.
} 
demes spent lavishly on their Dionysia', ${ }^{19}$ we should take note of the careful qualifications ('at the very latest', 'at least') that they both offer. ${ }^{20}$

A further strand of evidence can be discerned from the Athenians' reaction to Aeschylus' death in 456. Just two years previously Aeschylus had produced his masterpiece, the Oresteia; his death occurred at Gela during a visit to Sicily, but there is no reason to think that he had permanently abandoned Athens, whatever the insinuations of later biographers. ${ }^{21}$ When he died, the Athenians voted that anyone who wanted to produce his plays should be given a chorus. ${ }^{22}$ This claim is made in the ancient Life of Aeschylus, not all of which can relied on as fact, but it does not seem the kind of information that would be invented. There would have been more details to the decree than are preserved in the Life, not least the name of the festival at which these reperformances took place; but the basic story can relied on. ${ }^{23}$ There is a good parallel from later in the century, when Aristophanes' Frogs was reperformed by order of a decree of the assembly, because of the admiration won by its parabasis; this information comes to us from Dicaearchus via one of the hypotheses of the play. ${ }^{24}$

\footnotetext{
${ }^{19}$ Wilson 2008, 91 n. 11.

${ }^{20}$ Wilson 2000, 22 explicitly advocates an earlier date for deme reperformance: 'we should imagine the deme Dionysia, with their more flexible patterns of performance, as an important context from an early date for reperformance, although they hardly constituted a "repertory" circuit'.

${ }^{21}$ See Lefkowitz 2012, 74-6.

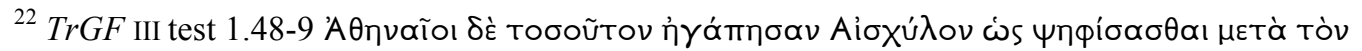

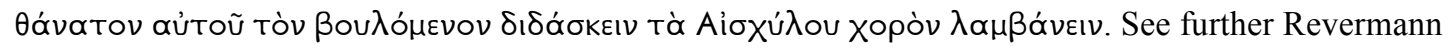
2006a, 72-3 and Lamari, this volume.

${ }^{23}$ It is consistent with Ar. Ach. 10-11 (from 425 BC), where Dicaeopolis expects to see a play by Aeschylus at a theatrical festival; see Olson 2002 ad loc.

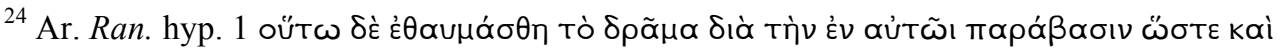

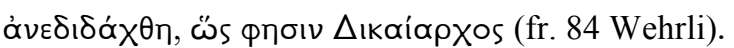


That reperformance is likely to have taken place in 404 , a year after the first performance; ${ }^{25}$ there is no indication that the play was reperformed more than once. For Aeschylus, however, the intention of the decree was to establish multiple reperformances, and there are indications that it achieved its aim; it is scarcely possible to imagine that the Electra plays of Sophocles and Euripides, for instance, were performed in front of an audience which had not recently had the opportunity to see Aeschylus' Oresteia, or at least his Choephoroe. ${ }^{26}$ No such provision is known for Sophocles; nor should we expect one. Sophocles was still alive and producing fresh works, so there was no need to instigate reperformances by decree to ensure that audiences could see his dramas; and since as a tragedian he was not able to put on a parabasis, in which he could have made direct recommendations to the people on matters of public policy, his plays were not going to win the particular type of recognition that was accorded to Aristophanes' Frogs. Neverthless, the evidence indicates that tragic reperformance was far from an unfamiliar concept in the midfifth century.

The presence of non-Athenians in the audience at the Dionysia, and to a lesser extent, at the Lenaea too, has implications for Sophoclean reperformance. ${ }^{27}$ Some of these foreigners will have been long-term residents in Attica, but others will have travelled for the festival, or will have visited it while in Athens on other business. As

\footnotetext{
${ }^{25}$ The parabasis in question encouraged the Athenians to restore political rights to those who had lost them thanks to their involvement in the oligarchic coup in 411; these rights were in fact restored in 404, after the disaster at Aegospotami led the Athenians to take drastic measures in their defence. A reperformance by decree would make sense in 404, as would the award to Aristophanes of an olive crown for his sentiments in the parabasis (test. 1.35-9 $P C G$ ).

${ }^{26}$ See further Reverman 2006b, 100-1 and Lamari, this volume.

${ }^{27}$ See Roselli 2011, 119-25.
} 
Taplin well asks, 'how long would it be before these visitors thought of arranging for performances to be put on back in their home-cities? ${ }^{28}$ We are familiar with the picture of Sophocles the Athenian patriot who, unlike Aeschylus and Euripides, never succumbed to the lures of foreign tyrants and kings in Sicily and Macedonia to perform, or reperform, his works abroad. ${ }^{29}$ But reperformance of his works outside Attica did not require his personal involvement, as long as the would-be producer could get hold of a script. We should not be surprised if plays by Sophocles were being reperformed outside Attica during his lifetime, with or without his blessing.

So far we have been forced to make inferences from data concerning other poets: a necessary approach when information is so scarce, but also a profitable one since it is reasonable to assume that there will have been many similarities in the reperformance practice of different playwrights. But we may now at last turn to some evidence which concerns Sophocles directly, to an inscription from the late fifth century, ${ }^{30}$ which attests to Sophocles' competing at the rural Dionysia, held in Eleusis. ${ }^{31}$ Two choregoi are said to have been victorious in the competitions for

\footnotetext{
${ }^{28}$ Taplin 1999, 37.

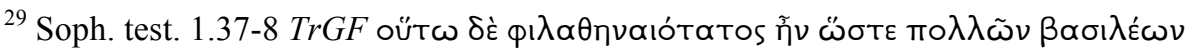

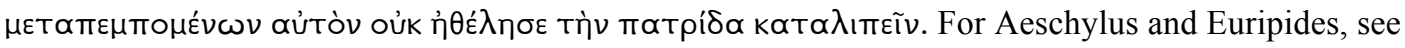
further Lamari and Fantuzzi, this volume.

${ }^{30} \operatorname{Tr} G F$ I DID B $3=$ Ar. test. $21 P C G=I G \mathrm{I}^{3}$ 970. Lewis (ap. $I G$ ) dates it between 425 and 406 (is the latter date chosen because it was the last year in which Sophocles could have competed in person?), but Csapo and Slater 1994, 129 put it in the last decade of the fifth century.

${ }^{31}$ The inscription used to be regarded as a commemoration of performances at the City Dionysia, until another inscription was published that made this impossible (see Csapo 2004a, 59-60). This reflects an old unwillingness to credit the major dramatists with participation in 'lesser' Attic festivals; Csapo (ibid. 70-3) shows that the idea that the Rural Dionysia was the province of unsophisticated hacks is based on misinterpretation of a number of passages.
} 
comedy, where Aristophanes was the producer, and for tragedy, in which the producer was Sophocles. The Sophocles in question is almost certainly our Sophocles, not his homonymous grandson, who won twelve victories, including at the Dionysia in 387 and 375, and who was responsible for the production of Oedipus at Colonus in 401. The latter only began to compete at the City Dionysia in his own right in $396 .^{32}$ It is conceivable that he performed in the demes before starting his career in the city, ${ }^{33}$ but that can only be surmise, when we known for certain that the elder Sophocles was competing in this period. The younger man's supervision of Oedipus at Colonus suggests that he did have theatrical experience, but that did not necessarily extend to the production of his own plays. Moreover, the success of Aristophanes in the comic competition makes it clear that this was no insignificant festival; in the contest for tragedy the experienced veteran Sophocles is a more plausible victor than his tiro grandson.

If, as is likely, the inscription does refer to the elder Sophocles, it provides proof of something that we have already surmised, namely that Sophocles competed in Attic festivals outside Athens. ${ }^{34}$ It does not prove that his entry at the Eleusis festival involved reperformance, but this is very probable. It would be too much even for someone as productive as Sophocles to devote a tragedy (or tragedies) to a single local festival, with a restricted audience, and not to perform it (them) in Athens and/or

\footnotetext{
${ }^{32}$ See $\operatorname{Tr} G F$ I 62 TT 3-6. For Sophocles' family see Sutton 1987, 15-16 (with a family tree).

${ }^{33}$ This is presumably what lies behind the suggestion by Snell ( $\operatorname{Tr} G F$ I $62 \mathrm{~T}$ 7) that the Eleusis inscription could refer to the younger Sophocles. Cf. Easterling 1990, 565 on new performances at the rural Dionysia: 'up-and-coming dramatists had to get their practice somewhere'.

${ }^{34}$ It is possible that the Eleusis festival was grander than that of most demes (cf. Allan 2001, 78, $84 \mathrm{n}$. 65), but the theatrical festivals at Rural Dionysia seem to have been associated in particular with the larger settlements (see n. 15 above).
} 
elsewhere in Attica as well. ${ }^{35}$ Moreover, the inscription shows that Sophocles was competing at a local festival in his mid-to-late eighties. ${ }^{36}$ Philoctetes and Oedipus at Colonus are proof that he retained his faculties, and his creativity, far into old age, ${ }^{37}$ this inscription suggests that his stamina suffered little diminution, either, since he was prepared to compete outside Athens at a time of his life when he might have been forgiven for concentrating on the city festivals or retiring altogether. The language of the inscription suggests that it was not simply his text that travelled to the deme festival: 'as the verb $\varepsilon \delta \delta ́ \delta \propto \sigma K \varepsilon v$ on choregic inscriptions always implies the function of "director", specifically "director of the chorus", and not the office of poet, the stone indicates the physical participation of Aristophanes and Sophokles in the production here commemorated ${ }^{38}$ It clearly was important to him to compete in person at a

\footnotetext{
${ }^{35}$ Cf. Dearden 1999, 224: 'we may surmise that the more famous playwrights were putting on repeat performances after initially presenting the plays at the more glamorous festivals but even this we cannot be sure of'; as his subsequent discussion makes clear, the doubt signalled in his final clause concerns whether or not the performance in Athens always occurred before performances in the demes, a question on which I too am agnostic and which does not affect the fundamental point that reperformance, in whatever sequence, is at issue here. Cf. Easterling 1990, 565, on our inscription: 'if the productions were premières this suggests that some of the deme festivals had acquired exceptional prestige; if (as is perhaps more likely) they were re-performances, they are evidence for the repertoire in the making'.

${ }^{36}$ This assumes that the dating advocated by Csapo and Slater (above, n. 29) is correct. If Lewis's date is right, the point still applies, but with considerably less force (Sophocles will then have been at least 65 when he competed at Eleusis).

${ }^{37}$ According to an apocryphal tale he recited a passage in court from the latter play to prove that he was in sound mind (test. 81-4 $\operatorname{Tr} G F$ ).

${ }^{38}$ Csapo 2004a, 59; cf. Csapo and Slater 1994, 129.
} 
deme festival, and if he was prepared to do this in old age, it is all but certain that he was doing so extensively earlier in his career. ${ }^{39}$

Another inscription may provide further evidence for Sophoclean reperformance in the demes. A fourth-century inscription from Halai Aixonides or Aixone was set up in honour of (at least) two choregoi, Epichares and Thrasybulus, presumably from the deme in question, celebrating their victories. A succession of entries, of which four are preserved, name in each case the choregos, specify whether the victory was in tragedy or comedy, then name the playwright/producer and the drama(s) in question. ${ }^{40}$ From the final entry we learn that one of Epichares' victories in the tragic competition occurred when Sophocles produced his Telepheia, or trilogy about Telephus. It is again possible that this 'Sophocles' is our Sophocles' grandson, but again, this is the less probable alternative. Among the attested plays of the elder Sophocles are three on the Telephus myth that could naturally form part of a trilogy on the subject: ${ }^{41}$ The Sons of Aleus, which probably dealt with the young Telephus' killing of his uncles, Mysians, in which Telephus arrived in Mysia from Arcadia, and Eurypylus, a play about how Telephus' son Eurypylus found a warrior's death at Troy. ${ }^{42}$ That does not prove that there was such a trilogy, but the data are at least consistent with there having been one.

\footnotetext{
39 'Even the Rural Dionysia secured top talent and possibly new works' (Csapo 2004b, 209, citing at pp. 209-10 n. 10 major dramatists who we know competed at that festival).

${ }^{40} \operatorname{Tr} G F$ I DID B $5=\operatorname{Tr} G F$ IV p. 434, on which see Finglass $2011,35$.

${ }^{41}$ I neglected to make this point in Finglass 2011, 35, and would now lean towards accepting that the

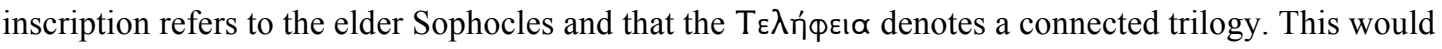
be the only connected trilogy attested for Sophocles.

${ }^{42}$ A further play called Telephus, attested once in Hesychius, is probably an alternative title for one of the plays in the Telephus trilogy.
} 
Granted that the Sophocles in question is our Sophocles, we must next ask where these victories occurred. ${ }^{43}$ The entry immediately preceding Sophocles', and the only other one recording a tragic victory, states that Timotheus won with two tragedies, Alcmeon and Alphesiboea. So that victory, at least, cannot have been at the Dionysia, ${ }^{44}$ although the Lenaea remains a possibility, and so does the rural Dionysia. The context of the inscription tells in favour of the last alternative. As Csapo points out, inscriptions for victories in the Rural Dionysia are found on marble statue bases in the Attic countryside, as was the Halai Aixonides inscription; by contrast, city festival victories prompted choregoi to dedicated paintings or reliefs at sanctuaries inside the city of Athens. ${ }^{45}$ And if the performance of Sophocles' Telepheia did indeed take place in one of the demes, it is more than possible that this involved reperformance. A trilogy (or tetralogy, if a satyr-play was involved) was a huge undertaking; it is most unlikely that Sophocles would have composed one for performance in a single deme and not elsewhere, whether in the city itself or around the deme circuit, except under extraordinary circumstances.

Festivals involving theatrical performance were the main occasions where reperformance of Sophoclean tragedy was possible. But we should not neglect a quite different reperformance context: symposia. Whole plays will not have been acted out at these gatherings, but individual speeches and songs will have been; and such informal reperformances will have done much to keep attenders of symposia familiar with the highlights of Sophocles' plays. A particular symposium at which one man

\footnotetext{
${ }^{43}$ Wilson 2000, 248-9 is inclined to accept performance in the city, but Wilson 2010, $41 \mathrm{n} .12$ refers approvingly to 'the growing tendency to ascribe the performance in $I G \mathrm{II}^{2}, 3091$ to Halai Aixonides rather than the City'. 
was expecting to hear some Aeschylus, and was distressed to hear some Euripides instead, is portrayed by Aristophanes in his Clouds of 423 BC. $^{46}$ Aristophanes does not include Sophocles at his symposium, but that is probably because Aeschylus and Euripides provided a more sharply contrasting pair than either of these figures would alongside Sophocles, who is anyway rarely mentioned by Aristophanes. The omission of Sophocles thus reflects the conventions of comedy, not any absence on his part from the institution of the symposium. ${ }^{47}$

A further type of evidence for reperformance may be furnished by the contents of the plays themselves. According to one line of analysis, playwrights included references to foreign locations in tragedy as a result of 'composing the play with future performances in mind outside Athens': ${ }^{48}$ such descriptions would have had particular appeal to people living in the places so described. With regard to Sophocles, the Thessalian location of his Trachiniae has been taken as a sign that it was intended for reperformance in Thessaly; Taplin suggests that the choral ode celebrating Thessaly, which places some emphasis on the festival of the Amphictyons at the sancturary at Pylae, ${ }^{49}$ might indicate a performance of the play at that very

\footnotetext{
${ }^{46}$ Ar. $N u b .1353-76$.

${ }^{47}$ For further evidence for tragedy and lyric at the symposium, especially in the fourth century, see Nervegna 2013, 169-71.

${ }^{48}$ Easterling 1994, 76. Cf. Roselli 2011, 143-4: 'references to foreign locations in tragedy may reflect a reperformance (or a first performance) abroad ... some localizations more immediately reflect an international audience within Attica' and ibid. 142 'the growth of the international theater industry may have increasingly become a fact of life for poets, who composed plays with multiple (and more generic) audiences in mind'. For such localisations see further Vahtikari (2014) 52-4.

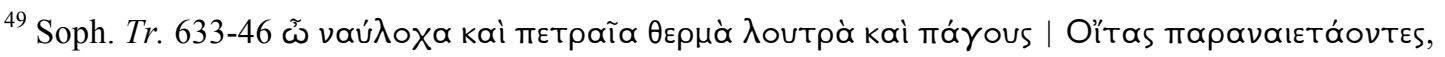

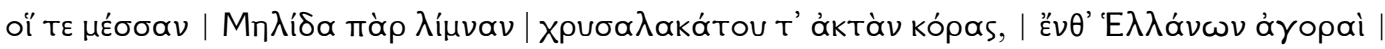

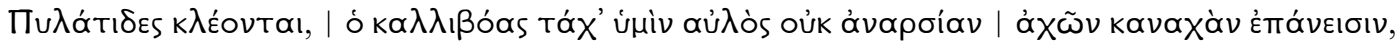


sanctuary. ${ }^{50}$ However, as he goes on to note, there is no evidence for theatrical performances at this festival; and a reference to it in Aristophanes emphasises its panhellenic rather than specifically Thessalian connexions. ${ }^{51}$ The emphasis in his Triptolemus on the spread of grain in the west might be taken as a sign that he was interested in having his plays reperformed in Sicily. ${ }^{52}$ An alternative model would see some localisations (not necessarily the ones just mentioned) as the result of interpolations by producers in situ, which subsequently entered the main textual tradition and hence appear in our manuscripts. ${ }^{53}$

This kind of analysis needs to be treated with caution. Part of the pleasure involved in theatrical entertainment is the diversion of the mind from everyday surroundings and the opening of vistas onto the unfamiliar. Most people today, I imagine, would resile from the idea that they are only or mainly interested in creative literature that deals with locations with which they have direct and personal familiarity; we should be careful of attributing to fifth-century Greeks any less sophistication in this matter. Since tragedy more often than not is concerned with

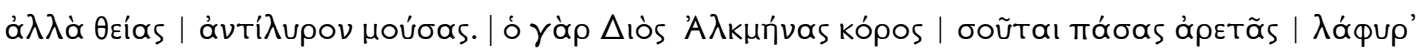

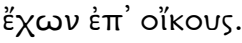

${ }^{50}$ Taplin 1999, 46: 'it seems plausible that [tragedies] should have been put on at this festival, and that this should be the audience (if any) to be pleased by Thessalian localizations'.

${ }^{51}$ Ar. Lys. 1128-32.

${ }^{52}$ Soph. frr. 598, $600 \operatorname{Tr} G F$. See Kowalzig 2008, 145-9, especially 147: 'even a superficial screening of Triptolemos' journeys westward raises a tantalizing issue . . . namely that Deinomenid grain power somehow had a role in tragic negotiation and affected where tragedy sailed to'.

${ }^{53}$ Cf. Revermann 2006a, 82: 'there is room for doubt whether such localizations are necessarily "built in" by the playwright rather than "edited in" by local producers, especially when the localization is not spread out (as at $<$ Soph. $>\operatorname{Tr}$. 197-229) or pervasive throughout a play (as are Thessalian localizations in the Alcestis) but short and focused on one place (as at Andromache 1243-9)'. 
myths set outside Attica, we would expect descriptions of non-Attic locales even if these plays were destined solely for performance in Athens and the demes. If the argument has any force, perhaps it is better put negatively, as it is by Heath when he says that 'tragedy was not in general so heavily marked by its Athenian and democratic context as to inhibit appreciation by non-citizens and by audiences in other cities. Tragedy's exportability proves this' ${ }^{54}$

Compared to the fifth century, the evidence for Sophoclean reperformance seems more abundant for the fourth. ${ }^{55}$ The first reperformance of Sophocles at the Dionysia will not have taken place before 386 , which according to an inscription is the first year that this practice took place. ${ }^{56} \mathrm{We}$ do not know which playwrights were chosen for this honour, but it would be foolhardy to assume that Sophocles was not one of them. Nor do we know whether the reperformances at this Dionysia were repeated at subsequent iterations of the festival, although that seems likely. The circumstances which prompted the inclusion of this new element of the competition will still have applied in 385 and in later years; moreover, it would be paradoxical to introduce reperformance, something that has repetition at its heart, as a one-off phenomenon. Certainly, tragic reperformance had become an established part of the festival by $341-339$, since in each of those three years a victory for 'old tragedy' is

\footnotetext{
${ }^{54}$ Heath 2011, 171.

${ }^{55}$ For a survey of the evidence for Sophoclean and Euripidean reperformance from the fourth century onwards see Nervegna 2014, 161-6.

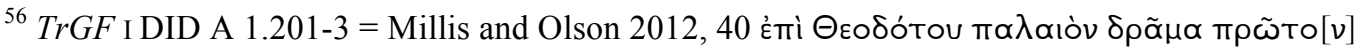
$\pi \propto \rho \propto \delta i ́ \delta \propto \xi \propto \nu$ oi $т \rho \propto \gamma[\omega \delta \circ$. For this event see further Hanink, this volume.
} 
recorded ${ }^{57}$ our evidence is so fragmentary that no conclusion can be drawn from its lack of attestation between 385 and 342 .

The institutionalisation of tragic reperformances in 386 at Attica's grandest festival involving drama reflects the immense status and prestige won and retained by the tragedians of the fifth century. ${ }^{58}$ It also "presuppose[s] that the habit [of reperformance] had been gaining momentum and popularity at local festivals for some time previously'; ${ }^{59}$ we can hardly imagine that, apart from the performance of Oedipus at Colonus in 401, the theatres of Attica never saw a performance by Aeschylus, Sophocles, or Euripides during the twenty years after the deaths of the latter pair. No doubt the families of these poets played a part in instigating reperformances of their works; the three just named all had family members still active in theatrical production. But (as Hall points out) 'pressure to introduce the revivals may also have come from the public, and more particularly from actors, who must have relished the opportunity to break free from contemporary playwrights. They could now build up a repertoire of famous roles contained in the old plays . . . they could tour with these celebrated roles to distant places if the pay was good enough' ${ }^{60}$ The very fact that reperformance at the Dionysia was instigated by actors ( $\pi \propto \rho \varepsilon \delta i ́ \delta \propto \xi \alpha \nu$ oi $т \rho \alpha \gamma[\omega \delta \circ i)$ is of great significance; in Csapo's words, 'this event . .. is the first time we see actors assuming a corporate identity, acting in concert (so to

\footnotetext{
${ }^{57} \operatorname{Tr} G F$ I pp. 13-14. In each case the winning play is by Euripides, thus giving him a more successful record in death than he ever had in life.

${ }^{58}$ Revermann 2006a, 74: the decision 'officially manifests a perception which pervades the Aristophanic Frogs: the notion of a caesura, the first and incipient monumentalization of "classics" and the formation of cultural icons'.

${ }^{59}$ Easterling 2006, 4.

${ }^{60}$ Hall 2007, 279.
} 
speak) and organizing the entirety of a production' ${ }^{61}$ The coming of reperformance to the City Dionysia is thus a product not only of the longstanding reperformance tradition within Attica, but also of the increasing importance of actors as professionals in their own right: something first formally acknowledged at the City Dionysia when the prize for the best actor was instituted between 450 and 447 inclusive. $^{62}$

Stories about individual actors in the fourth century sometimes involve reperformance of Sophocles' plays. The great actor Theodorus, 'already wealthy enough by 362 to make a large contribution to the rebuilding of the temple of Apollo at Delphi, ${ }^{63}$ played Antigone ${ }^{64}$ and Electra, ${ }^{65}$ and no doubt other parts as well. Aeschines often played Creon in Antigone, if we can trust Demosthenes. ${ }^{66}$ Demosthenes' dying words in Plutarch to his captor Archias, a former actor, associate him with performance of the same part. ${ }^{67}$ Archias' pupil was the actor Polos of Aegina, who was therefore active in the second half of the fourth century; ${ }^{68}$ when

\footnotetext{
${ }^{61}$ Csapo 2004a, 69. Cf. Nervegna 2007, 17: 'reperformances, unlike performances of new plays, clearly put actors in the spotlight, as they had both to produce and perform plays'.

${ }^{62}$ For the date see Millis and Olson 2012, 11-12.

${ }^{63}$ Hall 2007, 284 (with references and bibliography in n. 106).

${ }^{64}$ Dem. 19.246.

${ }^{65}$ So O’Connor 1908, 101 infers from Plut. Quaest. Conv. 737ab, probably rightly; cf. Duncan 2005, $59-63$.

${ }^{66}$ Dem. 19.246-8. For the passages in Demosthenes and Aeschines concerning the theatre see Easterling 1999, Hanink 2014, 129-58.

${ }^{67}$ Plut. Dem. 29.6. This may be a Plutarchan twist on the Demosthenes passages cited in the previous footnote. There the orator contrasts the behaviour of his great enemy with the noble sentiments voiced by Creon, whereas here he likens his foe to the same character; in both cases he is addressing an actor and explicitly invokes the theatrical dimension.

${ }^{68}$ Ibid. 28.3; cf. Philochorus FGrHist 328 F 222.
} 
performing the lead role in Electra at Athens, he is said to have delivered her famous lament over the supposed ashes of Orestes while holding an urn containing the remains of his own child. ${ }^{69} \mathrm{He}$ also played Oedipus in both Oedipus the King and Oedipus at Colonus, with equal facility. ${ }^{70} \mathrm{We}$ are also told about an actor called Timotheus of Zacynthus, whose fame for delivering Ajax's suicide speech was so

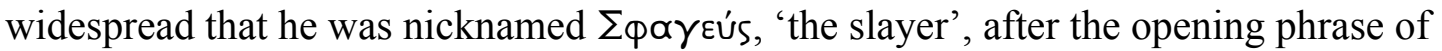
that speech; his date is unknown. ${ }^{71}$

These actors had a much wider range of contests to choose from, in Attica and elsewhere. As Csapo says, 'by the end of the fifth century Attica had at least six annual theatrical festivals, at least fifteen or sixteen by the mid-fourth, and a minimum of eighteen or nineteen in the late fourth century. By the last decades of the fifth century, theatrical festivals are attested in Macedonia and are probable for Syracuse, Taranto [i.e. Taras], Metapontum, Argos, Eretria, and Isthmia. They were widespread in Greece by the mid-fourth century, and ubiquitous by the late fourth. ${ }^{, 72}$ This circuit provided opportunities for actors, poets, and even spectators ${ }^{73}$ to put on and appreciate tragedy, and it would be extremely odd if Sophocles had not been well represented there.

\footnotetext{
${ }^{69}$ Aul. Gell. 6.5. For Polos see Easterling 2002, 335-6, Holford-Strevens 2005, Duncan 2005, 63-5.

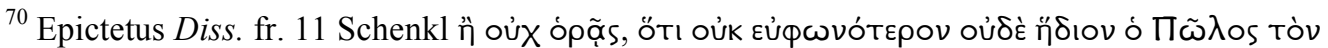

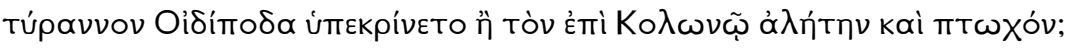

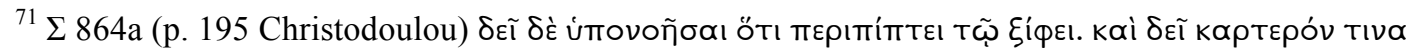

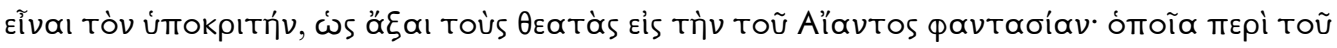

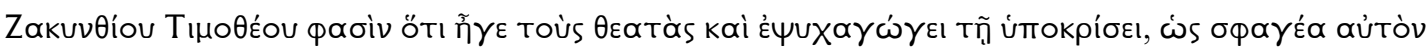

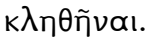

${ }^{72}$ Csapo 2004b, 208-9, with references in 208-9 n. 6.

${ }^{73}$ Cf. P1. Resp. 475d, cited above, n. 11.
} 
The fourth century is also the first time where a contribution is made by vase paintings to our understanding of this question. ${ }^{74}$ Several vases from south Italy and Sicily have been taken to show knowledge on the part of their painters (and audience) of specific performances of both tragedy and comedy. Some instances are universally accepted; others are more debatable. Taplin (2007), a recent discussion of this phenomenon across all classical tragedy and tragedians, discusses several vases with possible Sophoclean connexions, ${ }^{75}$ but his conclusion is pessimistic: 'there are very few [fourth-century vase paintings] that can be associated with [Sophocles'] plays without strong doses of wishful thinking. There may, indeed, be only two or three that can be connected with any confidence' ${ }^{76}$ The three in question are a Sicilian calyxkrater from c. 330 attributed to the Gibil Gabib Group, probably the Capodarso Painter, which probably depicts Sophocles' Oedipus the King, ${ }^{77}$ a Lucanian bellkrater from c. 350 attributed to the Sydney painter, thought to show his Electra; ${ }^{78}$ and an Apulian kalyx-krater from c. 340 close to the De Schulthess Painter, a likely representation of Oedipus at Colonus. ${ }^{79}$ The lack of evidence for Sophocles, as

\footnotetext{
${ }^{74}$ See Coo 2013 for a good analysis of the issues involved in using vases as evidence for knowledge of tragedy and tragic performance.

${ }^{75}$ Taplin 2007, 88-107.

${ }^{76}$ Ibid. 88 . Nervegna 2014, 173-4 is briefer but more optimistic, arguing that up to ten vases may show Sophoclean scenes.

${ }^{77}$ Syracuse, Museo Archeologico Regionale "Paolo Orsi” 66557; see Taplin 2007, 90-2 and Nervegna 2007, 17 n. 22.

${ }^{78}$ Vienna, Kunsthistorisches Museum 689 (Sk 195.69); see Taplin 2007, 96-7.

${ }^{79}$ Melbourne, Geddes Collection A 5:8; see Taplin 2007, 100-2 ('To any but the most skeptical, this new vase must be regarded as strong evidence that Sophocles' Oedipus (at Kolonos) was reperformed in Western Greece in the mid-fourth century, and that its message of mortal consolation amidst the sufferings of life was appreciated there', p. 102).
} 
opposed to Aeschylus and Euripides, may simply reflect the vagaries of transmission; on the other hand, 'there does seem to be reason to think that Sophocles was either less appreciated after the fifth century and outside Athens than the other two or regarded as less appropriate for interaction with vase-painting, ${ }^{80}$ Different sources state that the fourth-century tyrant Dionysius of Syracuse, himself a tragic poet, took steps to acquire the writing equipment of Aeschylus and Euripides. ${ }^{81}$ Apparently, however, he lacked interest in Sophocles' accoutrement; perhaps that may serve as a metaphor for the relative neglect of Sophocles compared to the other two 'classic' fifth-century dramatists in the west in that period.

On the other hand, we do have these three vases that reflect reperformances of Sophocles, from different regions of the Greek West. Perhaps there were fewer reperformances of Sophocles than of Euripides, but reperformances there evidently were. The audiences for these performances will naturally have included Greeks, but it is possible that non-Greek Italians also had an interest in Sophocles, at least if the vases are anything to go by. According to Carpenter, 'on the basis of evidence currently available [especially the distribution of the vases], it seems that Italic people, not Greeks, provided the principal market for vases with scenes that refer to

\footnotetext{
${ }^{80}$ Taplin 2007, 102.

${ }^{81} \operatorname{Tr} G F$ I 76 TT 10-11. Although the anecdote cannot be relied on, it is neverthless worth noting that for someone fashioning such a tale, either Aeschylus or Euripides would be an obvious poet to choose; the former because he visited Sicily more than once, and died there, the latter because of his greater popularity from the fourth century onwards (attested, however tenuously, in a Sicilian context in the story in Plut. Nic. 29.2-5 that some Athenian soldiers captured during the disastrous expedition in 413 won freedom or sustenance thanks to their being able to recite Euripides' verses to the Sicilians:

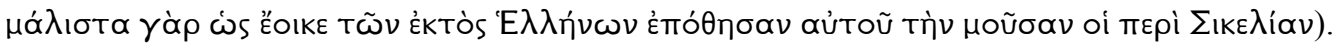
Evidence for a connexion between Sophocles and Sicily is limited to the Capodarso vase.
} 
Greek tragedies' ${ }^{82}$ If he is right, this suggests that non-Greeks had sufficient interest in Greek culture to want to see vases that made specific reference to the production of individual tragedies by classical dramatists. ${ }^{83}$ Such interest probably derives from reperformances of Sophocles' plays, watched not only by Greeks from outside Attica, but by native Italians whose culture was influenced by the Greeks settled nearby.

Neither of the two recent enormous companion volumes to Sophocles contains an entry under 'reperformance' in its index; the only references to this topic found in either book are brief. ${ }^{84}$ This is perhaps symptomatic of the current position of reperformance studies in tragic scholarship. The first performances continue to receive the lion's share of attention, naturally; for each drama, scholars attempt to reconstruct the original script and staging, and to imagine its impact on the original audience. The issue of reperformance might seem irrelevant to scholars with this focus. ${ }^{85}$ Moreover, as Csapo says, 'multiple productions . . . go very much against the grain of the romantic notion, still dear to classical scholarship, that all the expense and labor that went into the production of an ancient drama was sacrifice designed for a single immolation - a potlatch for the god Dionysus and the glory of Athens' ${ }^{86}$ But

\footnotetext{
${ }^{82}$ Carpenter 2009, 34; see further his article for evidence.

${ }^{83}$ Thus Lada-Richards 2009, 164-5 n. 190: 'If . . mythological vases found in the tombs of non-Greek settlements such as Ruvo were destined for a local, non-Hellenized market, that local market must have taken a keen interest in Athenian entertainment (introduced by itinerant troupes)'.

${ }^{84}$ Ormand 2012, Markantonatos 2012. There is, however, a helpful discussion of the subject in Wright 2012, 585-6.

${ }^{85}$ See however my other chapter in this volume, 'Reperformances and the transmission of texts', for suggestions as to why the study of reperformances may assist the analysis of first performances.

${ }^{86}$ Csapo 2010, 84. Cf. Arthur 1980, 9: 'the plays of Sophocles were written for performance, indeed primarily for one performance only'.
} 
the greater attention recently paid to this subject suggests that the two Companions may be somewhat behind the times in this regard. Without reperformance, we would not have any plays of Sophocles to read today - and without considering the early history of reperformance, we will never appreciate what Sophocles may have meant to the earliest generations who were privileged enough to be exposed to his work.

Christodoulou

FGrHist

FHG

$I G \mathrm{I}^{3}$

$P C G$
G. A. Christodoulou (ed.), Tà óox $\alpha \tilde{\imath} \alpha \sigma \chi o ́ \lambda ı \alpha$

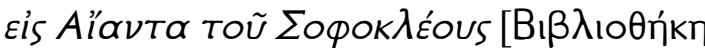

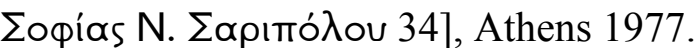
F. Jacoby et al. (eds.), Die Fragmente der griechischen Historiker, many vols. (Leiden, Boston, Cologne 1923-).

K. Müller and T. Müller (eds.), Fragmenta

Historicorum Graecorum, 5 vols. (Paris 184173).

D. M. Lewis et al. (eds.), Inscriptiones Atticae Euclidis anno anteriores, 3 vols. (Berlin and New York 1981-98).

R. Kassel and C. F. L. Austin (eds.), Poetae

Comici Graeci, 8 vols. (Berlin and New York 1983-2001).

Tragicorum Graecorum Fragmenta. Vol. 1

Didascaliae Tragicae, Catalogi Tragicorum et Tragoediarum, Testimonia et Fragmenta 
Tragicorum Minorum (ed. B. Snell, $2^{\text {nd }}$ ed. rev.

R. Kannicht; Göttingen $1971^{1}, 1986^{2}$ ); vol. 4

Sophocles (ed. S. L. Radt; $1977^{1}, 1999^{2}$ ).

Wehrli

F. Wehrli (ed.), Die Schule des Aristoteles:

Texte und Kommentar. Heft I: Dikaiarchos ${ }^{2}$,

Basel 1967. [1 ${ }^{\text {st }}$ edn 1944]

Allan, W. (2001), 'Euripides in Megale Hellas: some aspects of the early reception of tragedy', in: $G \& R 2^{\text {nd }}$ ser. $48,67-86$.

Arthur, E. P. (1980), 'Sophocles' Oedipus Tyrannos: the two arrivals of the herdsman', in: Antichthon 14, 9-17.

Baragwanath, E., and de Bakker, M. (2012), 'Introduction: myth, truth, and narrative in Herodotus' Histories', in: id. (eds.), Myth, Truth, and Narrative in Herodotus, Oxford, 1-56.

Carpenter, T. H. (2009), 'Prolegomenon to the study of Apulian red-figure pottery', in: $A J A 113,27-38$.

Coo, L. M.-L. (2013), ‘A Sophoclean slip: mistaken identity and tragic allusion on the Exter pelike', in: BICS 56, 67-88.

Csapo, E. (2004a), 'Some social and economic conditions behind the rise of the acting profession in the fifth and fourth centuries BC', in C. Hugoniot, F. Hurlet, and S. Milanezi (eds.), Le statut de l'acteur dans l'antiquité grecque et romaine. Actes du colloque qui s'est tenu à Tours les 3 et 4 mai 2002 [Collection perspectives historiques 9], Tours, 53-76. 
- (2004b), 'The politics of the new music', in P. Murray and P. Wilson (eds.), Music and the Muses. The Culture of "Mousike"” in the Classical Athenian City, Oxford, 207-48.

- (2010), Actors and Icons of the Ancient Theater, Malden, MA, Oxford, Chichester.

Csapo, E. G., and Slater, W. J. (1994), The Context of Ancient Drama, Ann Arbor. Dearden, C. (1999) 'Plays for export', Phoenix 53: 222-48.

Duncan, A. (2005) 'Gendered interpretations: two fourth-century B.C.E. performances of Sophocles' Electra', Helios 32: 55-79.

Easterling, P. E. (1990) 'The end of an era? Tragedy in the early fourth century', in A. H. Sommerstein, S. Halliwell, J. Henderson, and B. Zimmermann (eds.), Tragedy, Comedy and the Polis. Papers from the Greek Drama Conference, Nottingham, 18-20 July 1990, Bari, 559-69.

— (1994) 'Euripides outside Athens: a speculative note', ICS 19: 73-80.

— (1999), 'Actors and voices: reading between the lines in Aeschines and Demosthenes', in: S. Goldhill and R. Osborne (eds.), Performance Culture and Athenian Democracy, Cambridge, 154-66.

- (2002), 'Actor as icon', in ead. and E. M. Hall (eds.), Greek and Roman Actors. Aspects of an Ancient Profession, Cambridge, 327-41.

— (2006), 'Sophocles: the first thousand years', in: J. Davidson, F. Muecke, and P. Wilson (eds.), Greek Drama III. Essays in Honour of Kevin Lee [BICS Suppl. 87], London, 1-15.

Finglass, P. J. (2011), Sophocles. Ajax [Cambridge Classical Texts and Commentaries 48], Cambridge. 
- (2012), 'The textual transmission of Sophocles' dramas', in: K. Ormand (ed.), The Blackwell Companion to Sophocles, Malden, MA, Oxford, Chichester 924.

Hall, E. M. (2007) 'Greek tragedy 430-380 BC', in: R. Osborne (ed.), Debating the Athenian Cultural Revolution. Art, Literature, Philosophy, and Politics 430380 BC, Cambridge, 264-87.

Hanink, J. (2014) Lycurgan Athens and the Making of Classical Tragedy, Cambridge.

Heath, M. (2011), 'Response to Burian, Hesk, and Barker', in: D. M. Carter (ed.), Why Athens? A Reappraisal of Tragic Politics, Oxford, 163-71.

Holford-Strevens, L. (2005), 'Polus and his urn: a case study in the theory of acting, c. 300 B.C. - c. A.D. 2000 ', in: IJCT 11, 499-523.

Jones, N. F. (2004), Rural Athens under the Democracy, Philadelphia.

Kowalzig, B. (2008), 'Nothing to do with Demeter? Something to do with Sicily! Theatre and society in the early fifth-century west', in M. Revermann and P. Wilson (eds.), Performance, Iconography, Reception. Studies in Honour of Oliver Taplin, Oxford, 128-57.

Lada-Richards, I. (2009), “By means of performance”: western Greek mythological vase-paintings, tragic "enrichment", and the early reception of fifth-century Athenian tragedy', in: Arion 17/2, 99-166.

Lefkowitz, M. R. (2012), The Lives of the Greek Poets ${ }^{2}$, London. [1 ${ }^{\text {st }}$ edn 1981] Markantonatos, A. (2012) (ed.), Brill's Companion to Sophocles, Leiden and Boston. Marshall, H. R. (2012), 'Clouds, Eupolis and reperformance', in C. W. Marshall and G. Kovacs (eds.), No Laughing Matter. Studies in Athenian Comedy, London, 55-68. 
Millis, B. W., and Olson, S. D. (2012), Inscriptional Records for the Dramatic Festivals in Athens. IG II 2318-2325 and Related Texts, Leiden and Boston.

Nervegna, S. (2007), 'Staged scenes or plays? Theatrical revivals of "old” Greek drama in antiquity', in: ZPE 162, 14-42.

- (2013), Menander in Antiquity. The Contexts of Reception, Cambridge.

— (2014), 'Performing classics: the tragic canon in the fourth century and beyond', in: E. Csapo, H. R. Goette, J. R. Green, and P. Wilson (eds.), The Greek Theatre in the Fourth Century B.C., Berlin and Boston, 157-87.

O'Connor, J. B. (1908), Chapters in the History of Actors and Acting in Ancient Greece [Diss. Princeton], Chicago.

Olson, S. D. (2002), Aristophanes. Acharnians, Oxford.

Ormand, K. (2012) (ed.), The Blackwell Companion to Sophocles, Oxford.

Revermann, M. (2006a), Comic Business. Theatricality, Dramatic Technique, and Performance Contexts of Aristophanic Comedy, Oxford.

- (2006b), 'The competence of theatre audiences in fifth- and fourth-century Athens', in: JHS 126, 99-124.

Roselli, D. W. (2011), Theater of the People. Spectators and Society in Ancient Athens, Austin, TX.

Schenkl, H. (1916), Epicteti dissertationes ab Arriano digestae, Leipzig.

Scodel, R. (2012), 'Sophocles’ biography', in: K. Ormand (ed.), The Blackwell Companion to Sophocles, Oxford, 25-37.

Sommerstein, A. H. (2012), 'Fragments and lost tragedies', in: A. Markantonatos (ed.), Brill's Companion to Sophocles, Leiden and Boston, 191-209.

Sutton, D. F. (1987), 'The theatrical families of Athens', in: AJP 108, 9-26. 
Taplin, O. P. (1999), 'Spreading the word through performance', in: S. Goldhill and R. Osborne (eds.), Performance Culture and Athenian Democracy, Cambridge, 33-57.

- (2007) Pots and Plays. Interactions between Tragedy and Greek VasePainting of the Fourth Century B.C., Los Angeles.

Tyrrell, W. B. (2012), 'Biography', in: A. Markantonatos (ed.), Brill's Companion to Sophocles, Leiden and Boston, 19-37.

Vahtikari, V. (2014) Tragedy Performances outside Athens in the Late Fifth and the Fourth Centuries BC (Papers and Monographs of the Finnish Institute at Athens 20; Helsinki).

Wilson, P. (2000), The Athenian Institution of the Khoregia. The Chorus, the City and the Stage, Cambridge.

- (2008), 'Costing the Dionysia', in M. Revermann and P. Wilson (eds.), Performance, Iconography, Reception. Studies in Honour of Oliver Taplin, Oxford, 88-127.

— (2010) 'How did the Athenian demes fund their theatre?', in: B. Le Guen (ed.), L'argent dans les concours du monde grec. Actes du colloque international, Saint-Denis et Paris, 5-6 décembre 2008, Saint-Denis, 37-82.

Wright, M. E. (2012), 'The reception of Sophocles in antiquity', in: A. Markantonatos (ed.), Brill's Companion to Sophocles, Leiden and Boston, 581-99.

P. J. Finglass is Professor of Greek at the University of Nottingham; he has published editions of Sophocles' Electra (2007) and Ajax (2011), Pindar's Pythian Eleven (2007), and of Stesichorus (2014) with Cambridge University Press. 